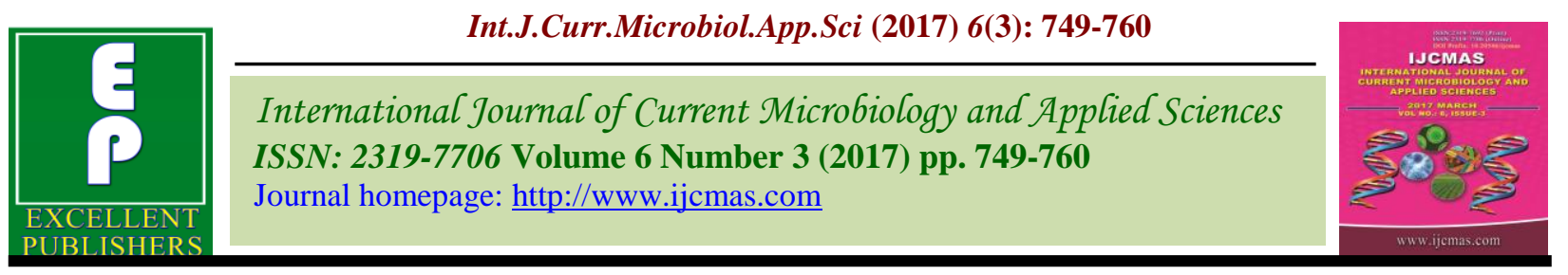

Original Research Article

https://doi.org/10.20546/ijcmas.2017.603.087

\title{
Genetic Variability, Heritability and Genetic Advance in Eggplant (Solanum melongena L.) Genotypes under Normal and Osmotic Stress in invitro condition
}

\author{
R. Gobu ${ }^{1 *}$, B.N. Harish Babu ${ }^{2}$, Kailash Chandra ${ }^{1}$, M. Shankar ${ }^{1}$ and Omprakash ${ }^{1}$ \\ ${ }^{1}$ Department of Genetics and Plant Breeding, Institute of Agricultural Sciences, Banaras Hindu \\ University, Varanasi, Uttar Pradesh, India \\ ${ }^{2}$ College of Horticulture, Hiriyur, UAHS, Shivamogga, Karnataka, India \\ *Corresponding author
}

\begin{tabular}{|c|c|}
\hline & A B S T R A C T \\
\hline $\begin{array}{l}\text { Ke y w or d s } \\
\text { Eggplant, } \\
\text { Brinjal, PEG-6000, } \\
\text { GCV, PCV, } \\
\text { Heritability, } \\
\text { Drought tolerance. }\end{array}$ & $\begin{array}{l}\text { The present investigation was carried out in } 73 \text { eggplant genotypes to assess the nature and } \\
\text { extent of genetic variability, heritability and genetic advance under normal ( } 0 \% \text { PEG- } 6000 \\
\text { as control) and osmotic stress condition (12\% PEG-6000) in germination phases in three } \\
\text { replications in a completely randomized design. The observations on germination per cent, } \\
\text { root, shoot and seedling length, fresh weight of seedlings and total dry matter were } \\
\text { recorded on tenth day after incubation. Further, seed vigour, root to shoot ratio, root length } \\
\text { stress tolerance index and plant height stress tolerance index were computed to understand }\end{array}$ \\
\hline Article Info & $\begin{array}{l}\text { the drought tolerance ability of the genotypes. The results of the analysis of variance for all } \\
\text { the characters studied were found to be highly significant in both the conditions indicating }\end{array}$ \\
\hline $\begin{array}{l}\text { Accepted: } \\
\text { 15 February } 2017 \\
\text { Available Online: } \\
10 \text { March } 2017\end{array}$ & $\begin{array}{l}\text { the availability of huge variability. A high range of variation and high heritability coupled } \\
\text { with high genetic advance was recorded for most of the traits. It indicates the broad genetic } \\
\text { base and less environmental influence which specifies the predominance of genetic factor } \\
\text { controlling variability. Hence, early generation selection schemes would be effective for } \\
\text { improvement and there is an ample scope for isolation of promising lines from the present } \\
\text { gene pool for drought tolerance. }\end{array}$ \\
\hline
\end{tabular}

\section{Introduction}

Eggplant commonly called as brinjal in India is grown in tropical and sub-tropical regions of the world. Eggplant is native to India where the major domestication of large fruited cultivars occurred. Eggplant is extensively grown in India, Bangladesh, China, Pakistan, Japan and Philippines. It is also popular in France, Italy, Egypt and United States. Eggplant is usually selfpollinated, but the extent of cross pollination has been reported to be as high as $48 \%$ and hence it is classified as often cross-pollinated- crop. Eggplant is reported to have the somatic chromosome number of $2 n=24$.

Although biotic stress has been reported as a major problem for eggplant production, recent abrupt climate change is making the abiotic stresses more common. Screening of eggplant cultivars against insect pests has been attempted by several workers elsewhere in India and abroad. But systematic research efforts for genetic improvement of eggplant for abiotic stress tolerance are not well 
pursued till recent times even in the light of having diverse germplasm resources.

Agronomical interventions have their own importance in abiotic stress tolerance, since genetic solutions are unlikely to close more than $30 \%$ of the gap between potential and realized yield under water stress (Edmeades $e t$ al., 2004). However improved genetics can be packed in a seed and easily be adapted than improved agricultural practices that depend more heavily on input availability, infrastructure, access to markets and skill in crop and soil management (Campos et al., 2004). So, the use of genetics and breeding aspects to improve drought tolerance capacity and provide yield stability is an important part of the solution to this dynamic problem.

However, breeding for water stress requires continuous efforts primarily, through the knowledge of genetic mechanism governing heritable parameters. Genetic effects of heritable parameters lead a plant breeder to a clear understanding of inheritance patterns of various plant traits as their relative contribution to the final yield.

Systematic improvement of any crop depends mainly on the information on genetic variability and diversity which forms the basis for any crop breeding programme. Further, the success of any crop improvement programme depends on the extent of genetic variability present in the population for the traits for which the improvement is aimed at. So, screening the cultivated varieties and germplasm lines for drought tolerance is the first step in developing varieties with both drought tolerance and high yield.

But drought tolerance screening under field conditions requires lot of resources (land, labour and other resources) and planning of the experiment. Further, it also depends on the environmental influences that affect phenotypic expression of a genotype. The study of the influence of the drought using osmotic solutions in germinal phase is one of the alternative methods for drought tolerance screening. Plants tolerant to both the biotic and the abiotic stresses can be acquired by applying the selecting agents such as $\mathrm{NaCl}$, for salt tolerance, polyethylene glycol (PEG) or mannitol, for drought tolerance (Errabii et al., 2008).

Polyethylene glycol is a better choice for imposing low water potential than the often used solute mannitol, because mannitol has been shown to be taken up by plant cells and can cause specific toxic effects on growth (Hohl and Schopfer, 1991; Verslues et al., 1998). Several authors reported the use of PEG for in vitro drought screening in crop plants (Thill et al., 1979; Dragiiska et al., 1996; Hassan et al., 2004; Manoj and Deshpande, 2005; Gopal and Iwama, 2007; Sakthivelu et al., 2008; Gobu et al., 2014b).

Screening genotypes at seedling stages have several benefits, such as screening large set of germplasm with less effort, more accuracy, low cost, ease of handling, less laborious and getting rid of susceptible genotypes at earliest. Furthermore, seedling traits have also shown moderate to high heritability with additive type of genetic variance within and over environments (Rauf et al., 2009). There are very scanty reports available on the genetics of drought tolerance in eggplant. So, the present work was carried out to know the nature and extent of genetic variability, heritability and genetic advance of traits involved in drought tolerance.

\section{Materials and Methods}

The research materials used in the study consisted of 73 genotypes which include five local cultivars, 36 released varieties and 32 germplasm lines. They were screened under 
drought stress (induced osmotic stress) and non-stress (normal) conditions (Figure 1). Each of the 73 genotypes was subjected to osmotic stress at germination stage induced by Polyethylene Glycol-6000 (PEG-6000) at $12.0 \%$ (equivalent to $-0.7 \mathrm{MPa}$, as described by Michel and Kaufmann, 1973) in 3 replications in a completely randomized design as reported by Harish Babu and Gobu (2016). For control, sterile distilled water was used instead of PEG-6000 for seed germination and seedling growth.

Thirty seeds per genotype were surface sterilized with $70 \%$ ethanol for 1 minute. Later, the seeds were washed thoroughly with sterile distilled water for three times and seeds were kept in petri-plates having moisturized germination paper. Seeds were moisturized with 12\% PEG-6000 solution for treatment plates and with sterile distilled water for control plates and were incubated for ten days at room temperature. At daily intervals, $1 \mathrm{ml}$ of PEG-6000 solution or sterile distilled water was added to petri-plates to keep the germination paper sufficiently moistened during the course of incubation. Seed germination was recorded on daily basis. The observations on germination per cent, root length, shoot length, seedling length, fresh weight of seedlings and total dry matter were recorded on tenth day after incubation (Figure 2). Further, seed vigour, root to shoot ratio, root length stress tolerance index, plant height stress tolerance index were computed to have a better understanding on their drought tolerance ability. Seed vigor was calculated using the following formula (ISTA, 1985).

Seed vigour $=$ Seedling length $(\mathrm{cm}) \times$ Germination percentage.

Root length stress tolerance index and plant height stress tolerance index were computed as given by Ashraf et al., (2006) using the following formula:
Root length stress tolerance index $=\frac{\text { Root length of stressed plants }(\mathrm{cm})}{\text { Root length of control plants }(\mathrm{cm})} \times 100$
Plant height stress tolerance index $=\frac{\text { Plant height of stressed plants }(\mathrm{cm})}{\text { Plant height of control plants }(\mathrm{cm})} \times 100$

The statistical analysis of the data on the individual characters was carried out on the mean values of ten random plants and analyzed by using Windostat software package (Version 9.2). The analysis of variance for each character was analyzed by adopting Completely Randomized Design as suggested by Cochran and Cox (1957). The mean, range and variance values of each character were calculated for each genotype. The coefficient of variation both at phenotypic and genotypic levels for all the characters were computed by applying the formula as suggested by Burton and Devane (1953). PCV and GCV were classified into low $(0-10 \%)$, moderate $(11-20 \%)$ and high (21\% and above) as suggested by Subramanian and Menon (1973). Heritability in broad sense for all the characters was computed by the formula suggested by Hanson et al., (1956). Heritability was classified into low $(0-30 \%)$, moderate $(31-$ $60 \%)$ and high (61 \% and above) as suggested by Robinson et al., (1949). The predicted genetic advance was estimated according to the formula given by Johnson and Robinson (1955). The genetic advance as per cent of mean was categorized into low (0 $-10 \%)$, moderate $(10.1-20 \%)$ and high (> 20.1 and above) as suggested by Johnson and Robinson (1955).

\section{Results and Discussion}

Analysis of variance was done to test the significance differences among genotypes studied in both moisture stress (12\% PEG6000) and normal condition (0 \% PEG-6000). Analysis of variance revealed that the genotypes under study differed significantly 
even at one per cent level of probability for all characters studied in both osmotic stress and normal conditions. The mean sum of squares of all the characters is presented in tables 1 and 2 for osmotic stress and normal conditions, respectively.

Comparison between phenotypic co-efficient of variation and genotypic co-efficient of variation for all the characters studied under stress and normal condition is represented in Chart 1. Comparison between broad sense heritability and genetic advance over mean under stress and normal condition is represented in Chart 2. The estimate of various genetic parameters under osmotic stress and normal condition is given in tables 3 and 4 respectively.

\section{Germination per cent}

The mean germination percentage under moisture stress induced by $12 \%$ PEG-6000 was in the range of 0 to 100 with an overall mean of $46.51 \%$. While under normal condition ( $0 \%$ PEG), the mean germination per cent recorded was 80.37 with a range of 13.33 to $100 \%$. Germination per cent in both control and stress condition showed high phenotypic co-efficient of variation (PCV) and genotypic co-efficient of variation (GCV) coupled with a high heritability. The GCV and PCV values recorded have narrow variation which indicates that this trait was less affected by environment.

This trait showed high genetic advance over mean (GAM) in both control and stress conditions. This result clearly depicts that the germination percentage can be used as a reliable parameter for selection of eggplant genotypes for drought tolerance. Similar results were reported by Abd El-Lattef et al., (2011) in rice.

\section{Root length}

Under moisture stress condition (12\% PEG6000 ), the mean root length recorded was $4.05 \mathrm{~cm}$ with a range of 0.00 to $9.45 \mathrm{~cm}$. However, under normal condition, the root length ranged from 0.10 to $9.01 \mathrm{~cm}$ with a mean of $4.81 \mathrm{~cm}$. The phenotypic and genotypic co-efficient of variability of root length in both stressed and control condition were high with high heritability and high genetic advance over mean indicating that the possibility of this trait is under the influence of additive gene action and scope for selection of genotypes for drought tolerance based on this trait.

\section{Shoot length}

The mean shoot length under moisture stress was $1.37 \mathrm{~cm}$ and ranged from 0.00 to 7.05 $\mathrm{cm}$. But under normal condition, the mean shoot length recorded was $3.69 \mathrm{~cm}$ with a range of 0.10 to $5.95 \mathrm{~cm}$. Shoot length showed high level of genotypic and phenotypic co-efficient of variability. It also possess high heritability with high genetic advance over mean in both stressed and control condition indicating meagre influence of environment.

\section{Seedling length}

The mean seedling length under moisture stress was $5.42 \mathrm{~cm}$ and was in the range of 0.00 to $13.58 \mathrm{~cm}$. 
Table.1 Analysis of variance in eggplant genotypes under moisture stress induced by $12 \%$ PEG-6000 in in vitro experiment

\begin{tabular}{|c|c|c|c|c|c|c|c|c|c|c|c|}
\hline Source & d.f & $\begin{array}{l}\text { Germination } \\
\text { per cent }(\%)\end{array}$ & $\begin{array}{c}\text { Root } \\
\text { length } \\
(\mathrm{cm})\end{array}$ & $\begin{array}{c}\text { Shoot } \\
\text { length } \\
(\mathbf{c m})\end{array}$ & $\begin{array}{c}\text { Seedling } \\
\text { length } \\
(\mathrm{cm})\end{array}$ & $\begin{array}{c}\text { Seed } \\
\text { vigour }\end{array}$ & $\begin{array}{c}\text { Root to } \\
\text { shoot } \\
\text { ratio } \\
\end{array}$ & $\begin{array}{c}\text { Fresh } \\
\text { weight } \\
\text { (mg) }\end{array}$ & $\begin{array}{c}\text { Dry } \\
\text { weight } \\
\text { (mg) }\end{array}$ & RLSI & PHSI \\
\hline Treatment & 72 & $3400.04^{* * *}$ & $1601.76^{\text {*** }}$ & $336.65^{* * *}$ & $41.95^{* * *}$ & $333559.31^{* *}$ & $15.32^{* * *}$ & $200.32^{* * *}$ & $15.94^{* * *}$ & $7639.80^{\circ}$ & 373.77 \\
\hline SEm & & 1.21 & 0.10 & 0.03 & 0.11 & 12.71 & 0.17 & 0.23 & 0.07 & 3.08 & 1.83 \\
\hline C.V. $(\%)$ & & 4.54 & 4.35 & 4.00 & 3.66 & 6.36 & 9.76 & 3.01 & 3.53 & 6.76 & 5.52 \\
\hline C.D. $1 \%$ & & 4.50 & 0.38 & 0.12 & 0.42 & 47.24 & 0.64 & 0.87 & 0.27 & 11.45 & 6.79 \\
\hline
\end{tabular}

Table.2 Analysis of variance in eggplant genotypes under normal condition (0 \% PEG-6000) in in vitro experiment

\begin{tabular}{|c|c|c|c|c|c|c|c|c|c|}
\hline Source & d.f. & $\begin{array}{c}\text { Germination per } \\
\text { cent }(\mathbf{c m})\end{array}$ & $\begin{array}{c}\text { Root } \\
\text { length } \\
(\mathbf{c m})\end{array}$ & $\begin{array}{c}\text { Shoot } \\
\text { length } \\
(\mathbf{c m})\end{array}$ & $\begin{array}{c}\text { Seedling } \\
\text { length } \\
(\mathbf{c m})\end{array}$ & $\begin{array}{c}\text { Seed } \\
\text { vigour }\end{array}$ & $\begin{array}{c}\text { Root to } \\
\text { shoot ratio }\end{array}$ & $\begin{array}{c}\text { Fresh } \\
\text { weight } \\
(\mathbf{m g})\end{array}$ & $\begin{array}{c}\text { Dry } \\
\text { weight } \\
(\mathbf{m g})\end{array}$ \\
\hline Treatment & 72 & $1707.00^{* *}$ & $12.89^{* *}$ & $7.49^{* *}$ & $36.27^{* *}$ & $441758.31^{* *}$ & $1.19^{* *}$ & $305.28^{* *}$ & $12.32^{* *}$ \\
\hline Error & 146 & 12.79 & 0.03 & 0.02 & 0.10 & 1429.81 & 0.01 & 0.92 & 0.02 \\
\hline SEm & 2.05 & 0.10 & 0.09 & 0.18 & 21.68 & 0.05 & 0.55 & 0.08 \\
\hline C.V. (\%) & 4.45 & 3.60 & 4.16 & 3.69 & 5.26 & 6.52 & 3.39 & 3.78 \\
\hline C.D. 5\% & & 5.77 & 0.28 & 0.25 & 0.51 & 61.02 & 0.15 & 1.54 & 0.22 \\
\hline C.D. 1 \% & & 7.62 & 0.37 & 0.33 & 0.67 & 8.58 & 0.20 & 2.04 & 0.29 \\
\hline
\end{tabular}

Where, d.f. - Degrees of freedom, RLSI - Root Length Stress tolerance Index, PHSI - Plant Height Stress tolerance Index ** - Significance @ 1\%, * - Significance @ 5\% 
Table.3 Estimates of genetic parameters in eggplant genotypes under osmotic stress induced by $12 \%$ polyethylene glycol-6000 [PEG-6000] in in vitro experiment

\begin{tabular}{|c|l|c|c|c|c|c|c|}
\hline S.No. & \multicolumn{1}{|c|}{ Character } & Mean & Range & PCV $(\%)$ & GCV $(\%)$ & $h^{2}(\%)$ & GAM $(\%)$ \\
\hline 1 & Germination percent $(\%)$ & 46.51 & $0.00-100.00$ & 72.48 & 72.34 & 99.61 & 148.73 \\
\hline 2 & Root length $(\mathrm{cm})$ & 4.05 & $0.00-9.45$ & 67.32 & 67.18 & 99.58 & 138.10 \\
\hline 3 & Shoot length (cm) & 1.37 & $0.00-7.05$ & 91.20 & 91.11 & 99.81 & 187.51 \\
\hline 4 & Seedling length (cm) & 5.42 & $0.00-13.58$ & 69.05 & 68.95 & 99.72 & 141.85 \\
\hline 5 & Seed vigour & 348.72 & $0.00-1068.90$ & 95.76 & 95.55 & 99.56 & 196.40 \\
\hline 6 & Root to shoot ratio & 3.08 & $0.00-13.46$ & 73.76 & 73.11 & 98.25 & 149.29 \\
\hline 7 & Fresh weight (mg) & 13.59 & $0.00-31.40$ & 60.19 & 60.11 & 99.75 & 123.68 \\
\hline 8 & Dry weight (mg) & 3.58 & $0.00-7.34$ & 64.42 & 64.32 & 99.70 & 132.31 \\
\hline 9 & RLSI & 79.49 & $0.00-217.39$ & 63.73 & 63.37 & 98.88 & 129.80 \\
\hline 10 & PHSI & 57.69 & $0.00-131.58$ & 61.79 & 61.54 & 99.20 & 126.26 \\
\hline
\end{tabular}

Table.4 Estimates of genetic parameters in eggplant genotypes under normal conditions (0 \% PEG-6000) in in vitro experiment

\begin{tabular}{|c|l|c|c|c|c|c|c|}
\hline S.No & \multicolumn{1}{|c|}{ Character } & Mean & Range & PCV $(\%)$ & GCV $(\%)$ & $h^{2}(\%)$ & GAM $(\%)$ \\
\hline 1 & Germination percent (\%) & 80.37 & $13.33-100.00$ & 29.90 & 29.57 & 97.79 & 60.24 \\
\hline 2 & Root length $(\mathrm{cm})$ & 4.81 & $0.10-9.01$ & 43.15 & 43.00 & 99.30 & 88.27 \\
\hline 3 & Shoot length (cm) & 3.69 & $0.10-5.95$ & 43.00 & 42.80 & 99.06 & 87.74 \\
\hline 4 & Seedling length $(\mathrm{cm})$ & 8.50 & $0.20-14.16$ & 41.01 & 40.84 & 99.19 & 83.79 \\
\hline 5 & Seed vigour & 718.8 & $4.00-1415.67$ & 53.57 & 53.31 & 99.04 & 109.28 \\
\hline 6 & Root to shoot ratio & 1.45 & $0.47-4.60$ & 43.69 & 43.20 & 97.78 & 88.01 \\
\hline 7 & Fresh weight (mg) & 28.32 & $4.32-52.30$ & 35.73 & 35.57 & 99.11 & 72.94 \\
\hline 8 & Dry weight (mg) & 3.54 & $1.20-18.00$ & 57.32 & 57.20 & 99.56 & 117.57 \\
\hline
\end{tabular}

\section{Where,}

RLSI - Root Length Stress tolerance Index, PHSI - Plant Height Stress tolerance Index, PCV - Phenotypic Co-efficient of Variation, GCV - Genotypic Co-efficient of Variation, $h^{2}-$ Broad Sense Heritability, GAM - Genetic Advance as percent over Mean 
Fig.1 General view of in vitro studies using PEG-6000 for drought tolerance screening in eggplant at germination stage
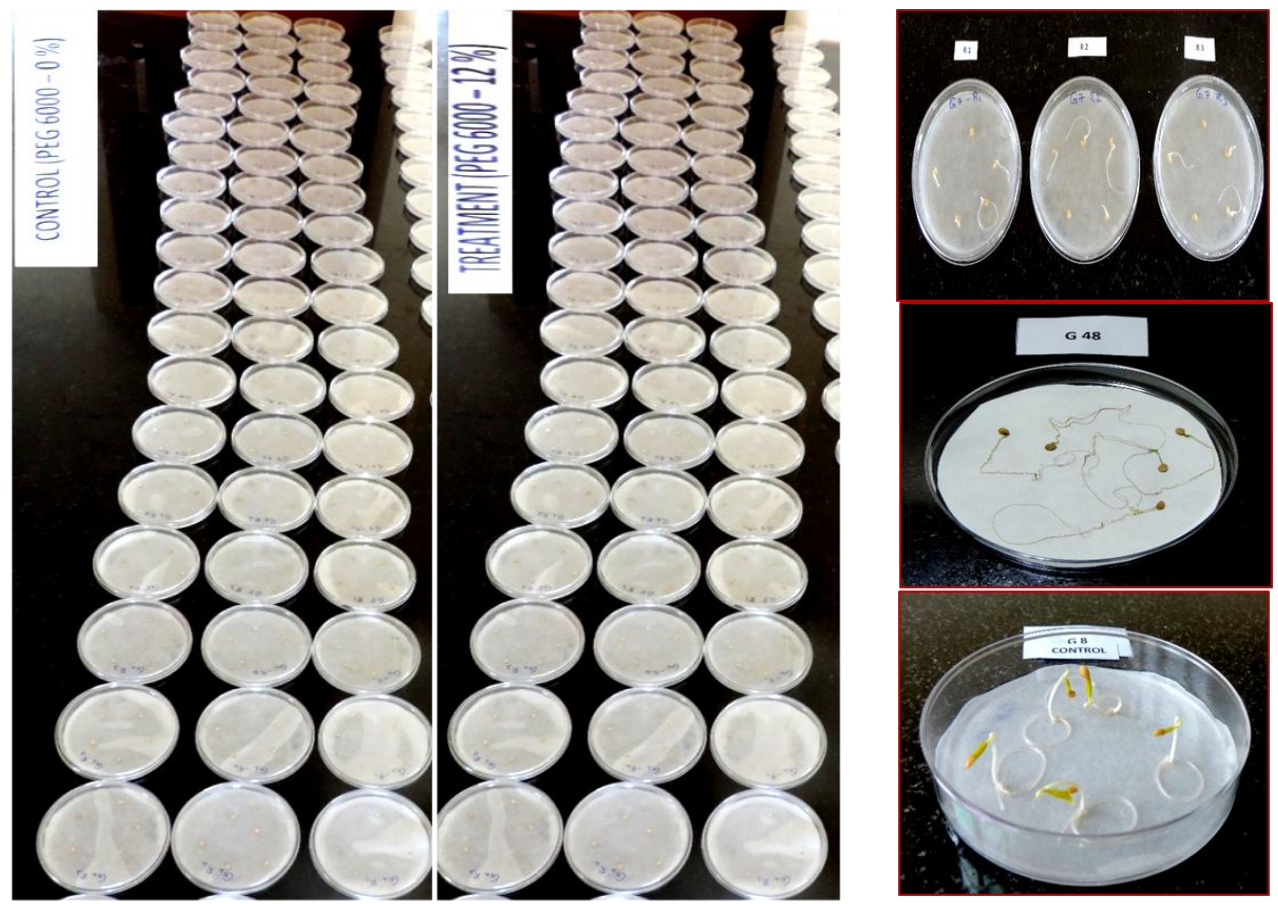

Normal condition: 0\% PEG-6000

Moisture stress: 12\% PEG-6000

Fig.2 Seedling growth in different eggplant genotypes under osmotic stress (12\% PEG-6000) and normal conditions (0\% PEG-6000)
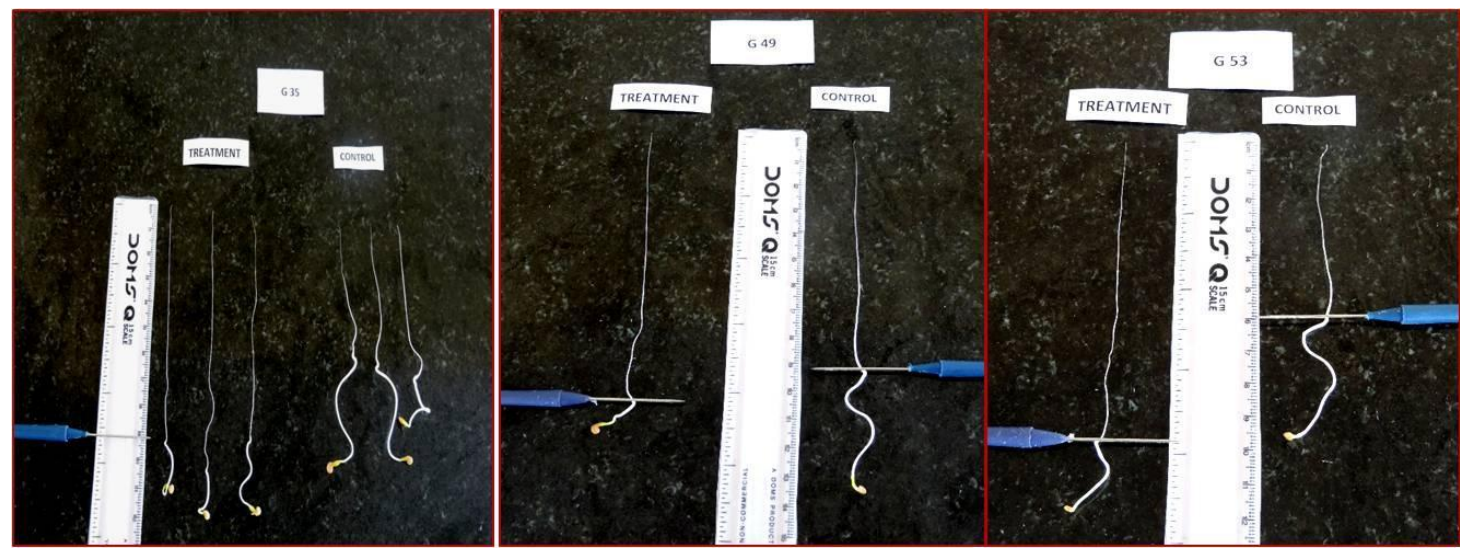
Chart.1 Comparison between phenotypic co-efficient of variation (PCV) and genotypic co-efficient of variation (GCV) for all the characters studied in in vitro screening under stress (12\% PEG-6000) and normal condition (0\% PEG-6000)

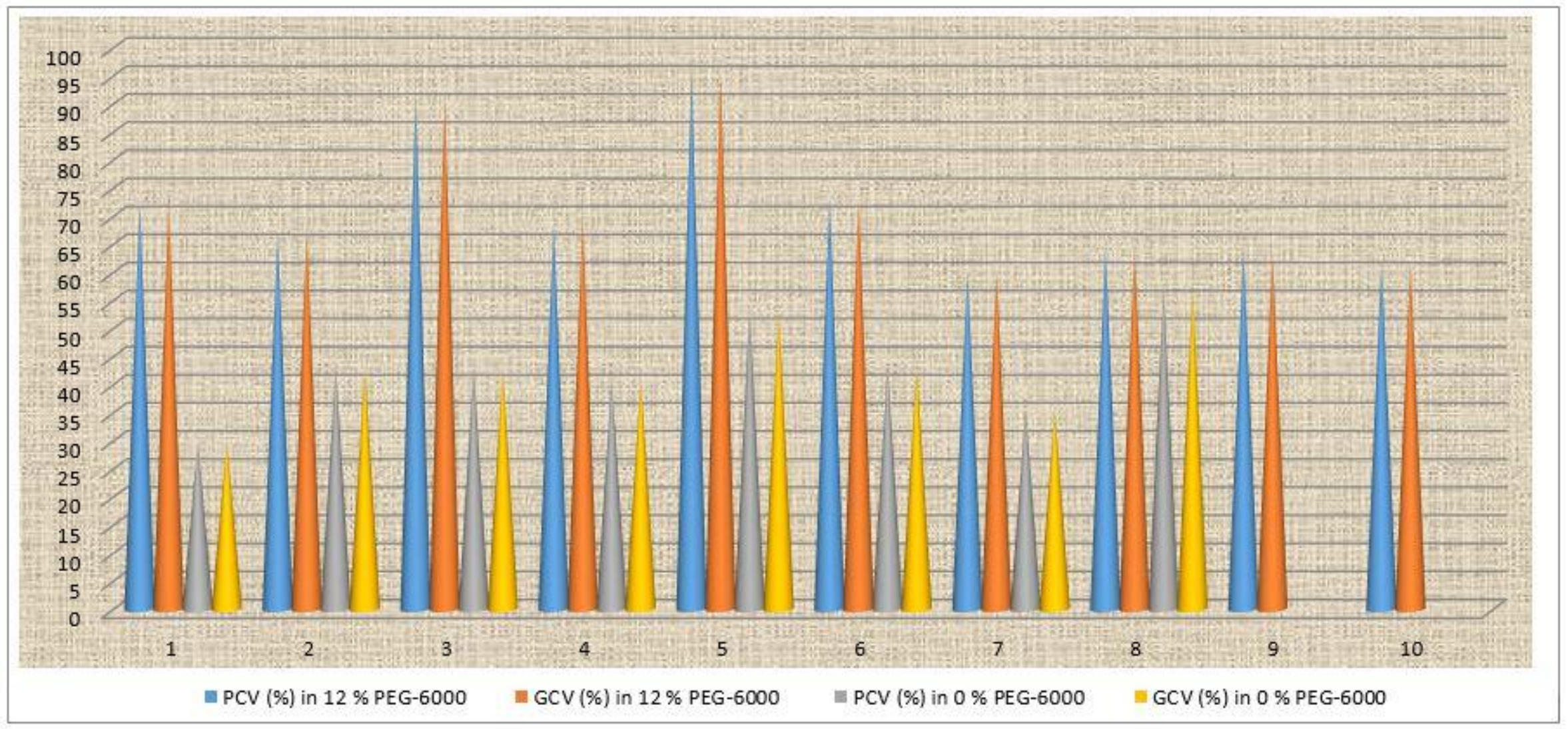

Where, 1. Germination per cent, 2.Root length (cm), 3. Shoot length (cm), 4. Seedling length (cm), 5. Seed vigour, 6. Root to shoot ratio, 7. Fresh weight $(\mathrm{mg}), 8$. Dry weight $(\mathrm{mg}), 9$. Root length stress tolerance index, 10. Plant height stress tolerance index 
Chart.2 Comparison between broad sense heritability and genetic advance over mean (GAM) for all the characters studied in in vitro screening under stress (12\% PEG-6000) and normal condition (0\% PEG-6000)

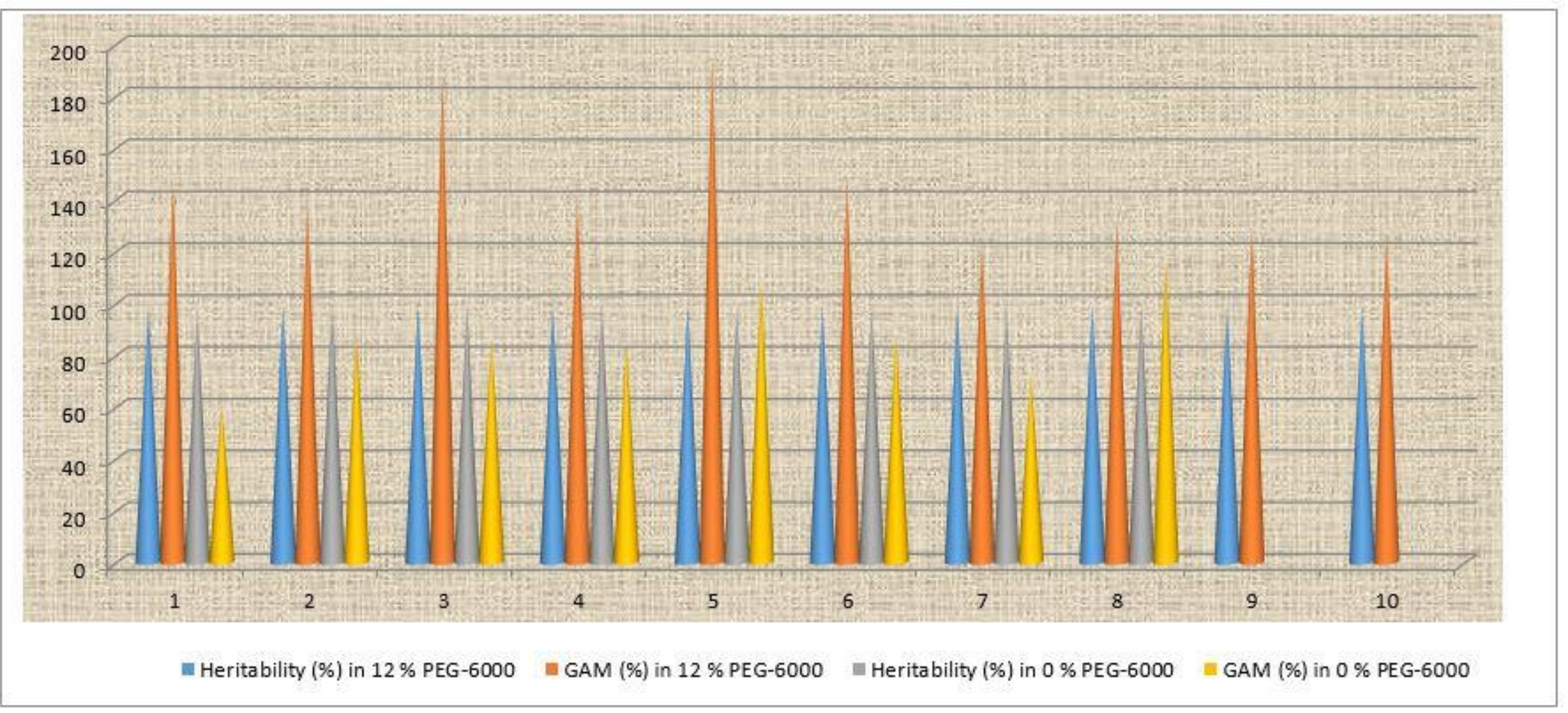

Where, 1. Germination per cent, 2.Root length (cm), 3. Shoot length (cm), 4. Seedling length (cm), 5. Seed xigour, 6. Root to shoot ratio, 7. Fresh weight (mg), 8. Dry weight (mg), 9.Root length stress tolerance index, 10. Plant height stress tolerance index 
On the contrary, the mean seedling length under normal condition was $8.50 \mathrm{~cm}$ with a range of 0.20 to $14.16 \mathrm{~cm}$. For seedling length, coefficient of variability observed at phenotypic and genotypic level was high. It showed high heritability with high genetic advance over mean.

\section{Seed vigour}

The seed vigour under moisture stress was in the range of 0 to 1068.90 with a mean of 348.72. However, under normal condition, the mean seed vigour was 718.8 . The lowest and highest seed vigour recorded was 4.00 and 1415.67, respectively. Seed vigour exhibited high genotypic and phenotypic co-efficient of variation. It also had high heritability indicating that it is less influenced by environmental factors. It had high genetic advance over mean.

\section{Root to shoot ratio}

The mean root to shoot ratio under moisture stress was 3.08 and it was in the range of 0.00 to 13.46. Under normal condition, the root to shoot ratio was in the range of 0.47 to 4.60 with a mean of 1.45. Root to shoot ratio showed high genotypic and phenotypic coefficient of variation. This trait exhibited high heritability with high genetic advance over mean and this trait is known to play a pivotal role in drought tolerance, so selection based on this trait will lead to a better drought tolerant genotype.

\section{Fresh weight of the seedlings}

The minimum and maximum fresh weight of the seedlings under moisture stress was 0.00 and $31.40 \mathrm{mg}$, respectively with a mean of $13.59 \mathrm{mg}$. The fresh weight of the seedlings under normal condition ranged from 4.32 to $52.30 \mathrm{mg}$ with a mean of $28.32 \mathrm{mg}$. Fresh weight of the seedlings in both stressed and control condition showed high genotypic and phenotypic co-efficient of variability. In addition, it exhibited high heritability along with high genetic advance over mean.

\section{Dry weight of the seedlings}

Under the moisture stress induced by $12 \%$ PEG-6000, the dry weight of the seedlings ranged from 0.00 to $7.34 \mathrm{mg}$ with a mean of $3.58 \mathrm{mg}$. In case of normal condition, the mean dry weight of the seedlings was $3.54 \mathrm{mg}$ and ranged from 1.20 to $18.00 \mathrm{mg}$. Dry weight of the seedlings showed high genotypic and high phenotypic co-efficient of variability. It also had high heritability and high genetic advance over mean.

\section{Root length stress tolerance index (RLSI) and Plant height stress tolerance index (PHSI)}

The mean RLSI observed was 79.49 and it ranged from 0.00 to 131.58 . The PHSI ranged between 0.00 and 131.58 with a overall mean of 57.69. Root length stress tolerance index and plant height stress tolerance index showed a high genotypic and phenotypic coefficient of variability. Both of these traits exhibited high heritability, genetic advance over mean and have a key role in drought tolerance screening. These traits can be utilized effectively for selecting genotypes with moisture tolerance capacity. Similar conclusions were arrived at the research findings of Ahmad et al., (2009) and Saensee et al., (2012).

From all the above results, it is evident that a vast genetic variability exists among eggplant genotypes for drought tolerance with high heritability. Further, these genotypes can be additionally screened by field evaluation methods to validate drought resistant genotypes. This would further help in identifying genotypes having better drought 
tolerance characteristics which may be of great use in breeding for drought tolerance in eggplant.

\section{References}

Abd El-Lattef, A.S.M., Aml E.A., El-Saidy, W.H.M., El-Kallawy and Mady, A.A., 2011. Evaluation of some rice (Oryza sativa L.) genotypes under water stress conditions. J. Plant Production, 2(2): 307-326.

Ahmad, S., Ahmad, R., Ashraf, M.Y., Ashraf, M. and Waraich, E.A., 2009. Sunflower (Helianthus annuus L.) response to drought stress at germination and seedling growth stages. Pak. J. Bot., 41(2): 647-654.

Ashraf, M.Y., Akhtar, K., Hussain, F. and Iqbal, J., 2006. Screening of different accessions of three potential grass species from Cholistan desert for salt tolerance. Pak. J. Bot., 38: 1589-1597.

Burton, G.N. and Devane, E.M. 1953. Estimating heritability in tall fescue (Festuca arundianacea L.) from replicated clonal material. Agron. J., 45: 478-481.

Campos, H., Cooper, M., Habben, J.E., Edmeades, G.O. and Schussler, J.R. 2004. Improving drought tolerance in maize: A view from industry. Field Crops Res., 90: 19-34.

Cochran, W.G. and Cox, G.M. 1957. Experimental Designs. John Wiley and Sons, Inc., New York, pp. 611.

Dragiiska, R., Djilianov, D., Denchev, P. and Atanassov, A., 1996. Invitro selection for osmotic tolerance in alfalfa (Medicago sativa). Bulg. J. Plant Physiol., 22: 30-39.

Edmeades, G.D., Banziger, M., Schussler, J.R. and Campos, H. 2004. Improving abiotic stress tolerance in maize: a random or planned process. In proceedings of the Intl. symp. on $\mathrm{Pl}$.
Breeding, Lowa State University Press. Errabii, T., Gandonou, C. B., Essalmani, H., Abrini, J., Idaomar, M. and Senhaji, N. S., 2008. Growth, proline and ion accumulation in sugarcane callus cultures under drought-induced osmotic stress and its subsequent relief. African J. Biotech., 5: 1488-1493.

Gobu, R., Harish Babu, B.N., Thimmanna, D., Gangaprasad, S. and Dushyantha Kumar, B.M. 2014b. Standardization of in vitro screening method for drought tolerance in eggplant (Solanum melongena L.) using Polyethylene Glycol induced osmotic stress. Proc. 6th Indian Hort. Congress, Nov. 6-9, Coimbatore.

Gopal, J. and Iwama, K., 2007. Invitro screening of potato against water stress mediated through sorbitol and polyethylene glycol. Plant Cell Report, 26: 693-700.

Hanson, C.H., Robinson, H.R. and Comstock, R.S. 1956. Biometrical studies of yield in segregating population of Korean lespedeza. Agron. J., 48: 268-272.

Harish Babu, B.N. and Gobu, R. 2016. Optimization of osmotic stress induced by different concentrations of Polyethylene Glycol-6000 for drought tolerance screening in eggplant (Solanum melongena L.,). Int. J. Scientific Res., 5(2): 205-206.

Hassan, N.S., Shaaban, L.D., El-Sayed, A.H. and Seleem, E.E. 2004. Invitro selection for water stress tolerant callus line of Helianthus annus L. Cv Myak. Int. J. Agric. Biol., 56: 132-136.

Hohl, M. and Schopfer, P., 1991. Water relations of growing maize coleoptiles. Plant Physiol., 95: 716-722.

ISTA. 1985. International rules for seed testing. Seed Sci. and Technol., 13: 307355.

Johnson, H.W. and Robinson, H.F. 1955. Estimates of genetic and environmental 
variability in soybean. Agron. J., 47: 314-318.

Manoj, K. and Deshpande, U.D. 2005. Invitro screening of tomato genotypes for drought resistance using PEG-6000. Veg. Sci., 32(1): 11-14.

Michel, B.E. and Kaufmann, M.R. 1973. The Osmotic Potential of Polyethylene Glycol 6000. Plant Physiol., 51: 914916.

Rauf, S., Sadaqat, H.A., Ahmad, R. and Khan, I.A. 2009. Genetics of root characteristics in sunflower (Helianthus annuus L.) under contrasting water regimes. Indian J. Plant Physiol., 14(4): 319-327.

Robinson, H.F., Comstock, R.E. and Harvey, V.H. 1949. Estimates of heritability and degree of dominance in corn. Agron. J., 41: 353-359.

Saensee, K., Machikowa, T. and Muangsan, N. 2012. Comparative performance of sunflower synthetic varieties under drought Stress. Int. J. Agric. Biol., 14(6): 929-934.

Sakthivelu, G., Akitha, D.M.K., Giridhar, P., Rajasekaran, T., Ravishankar, G.A., Nedev, T. and Kosturkova, G. 2008. Drought-induced alterations in growth, osmotic potential and invitro regeneration of soybean cultivars. Gen. Appl. Plant Physiol., 34(1-2): 103-112.

Subramanian, S.S. and Menon, M. 1973. Heterosis and inbreeding depression in rice. Madras Agril. J., 60: 1139.

Thill, D.C., Schimman, R.D. and Appeby, A. P. 1979. Osmotic stability of mannitol and polyethylene glycol 20000 solutions used as seed germination media. Agron. J., 71: 105-108.

Verslues, P.E., Ober, E.S. and Sharp, R.E. 1998. Root growth and oxygen relations at low water potentials. Impact of oxygen availability in polyethylene glycol solutions. Plant Physiol., 116: 1403-1412.

\section{How to cite this article:}

Gobu, R., B.N. Harish Babu, Kailash Chandra, M. Shankar and Omprakash. 2017. Genetic Variability, Heritability and Genetic Advance in Eggplant (Solanum melongena L.) Genotypes under Normal and Osmotic Stress in invitro condition. Int.J.Curr.Microbiol.App.Sci. 6(3): 749760. doi: https://doi.org/10.20546/ijcmas.2017.603.087 